\title{
Pembelajaran Bahasa Inggris pada Anak di Sangkhom Islam Wittaya School saat Pandemi Covid-19
}

\author{
Muammar Qadafi ${ }^{凶}$ \\ Pendidikan Islam Anak Usia Dini, Universitas Islam Negeri Mataram \\ DOI: $\underline{10.31004 / o b s e s i . v 5 i 1.591}$
}

\begin{abstract}
Abstrak
Kebijakan study from home selama pandemi COVID-19 menimbulkan masalah baru bagi pendidikan anak usia dini. Penelitian ini bertujuan untuk mengidentifikasi dan mendeskripsikan prolematika dan strategi yang digunakan oleh guru dalam pembelajaran Bahasa Inggris untuk anak usia dini selama pandemi COVID-19 di Sangkhom Islam Wittaya School Thailand. Penelitian menggunakan metode kualitatif dengan pendekatan studi kasus. Subjek penelitiannya adalah tiga orang guru Bahasa Inggris yang berasal dari Indonesia. Hasil penelitian menunjukkan bahwa permasalahan terdapat pada proses adaptasi pola baru yang mengharuskan guru, siswa, serta orang tua untuk meningkatkan kompetensi di bidang teknologi; keterampilan Bahasa Inggris orang tua yang tidak memadai; dan biaya operasional untuk membeli paket data internet. Sedangkan strategi yang digunakan oleh guru adalah menjalin komunikasi dengan orang tua untuk memberikan informasi terkait rencana pembelajaran, menyiapkan materi dengan menggunakan video maupun lembar kegiatan atau tugas yang mudah dipahami, dan menyiapkan platform pembelajaran online seperti YouTube, line group, dan google classroom.
\end{abstract}

Kata Kunci: problematika dan strategi; bahasa inggris; covid-19

\begin{abstract}
The policy of study from home during the COVID-19 pandemic caused new problems for early childhood education. This study aims to identify problems and strategies used by teachers in learning English for early childhood during the COVID-19 pandemic at Sangkhom Islam Wittaya School Thailand. This is a qualitative research with a case study approach. The research subjects are three Indoesian nationality English teachers. The results of the study indicate that the problem lies in the process of adaptation to new patterns that require teachers, students, and parents to improve their competence in technology; parents' English competence; and the operational cost for internet access. While the strategy used by teachers are to establish communication with parents to provide information related to learning plans, prepare material using videos or sheet activities or assignments, and prepare online learning platforms such as YouTube, line groups, and google classroom.
\end{abstract}

Keywords: problems and strategies; english; covid-19

Copyright (c) 2020Muammar Qadafi

$\triangle$ Corresponding author :

Email Address : mqadafi31@uinmataram.ac.id (Jln. Sunan Giri Raya Blok M 03, Kota Mataram NTB)

Received 4 June 2020, Accepted 12 June 2020, Published 7 July 2020 


\section{PENDAHULUAN}

Sejak bulan Desember 2019, masyarakat global sedang dilanda pandemi virus COVID-19 yang menyebabkan perubahan tatanan kehidupan sosial, termasuk dunia pendidikan (Arango, 2020). COVID-19 adalah salah satu penyakit menular yang disebabkan oleh jenis corona virus yang baru ditemukan di Kota Wuhan, China (WHO, 2020). Transmisi virus ini terjadi antar manusia, sehingga penyebarannya menjadi sangat cepat. Pada saat penyebaran virus mulai masuk ke Thailand, pemerintah menentukan berbagai peraturan yang dapat memenghambat transmisi dari penderita kepada orang yang sehat. Salah satu peraturannya adalah keharusan untuk melakukan social/physical distancing. Social/physical distancing merupakan salah satu pendekatan yang dapat memutus mata rantai penyebaran virus tersebut. Pernyataan ini diperkuat oleh penelitian yang dilakukan di Amerika yang menujukkah bahwa social distancing dapat menyelamatkan lebih dari 1 juta nyawa (Greenstone \& Nigam, 2020).

Peraturan social/physical distancing ini mendasari penutupan tempat-tempat yang berpotensi menimbulkan keramaian, salah satunya adalah lembaga pendidikan, mulai dari perguruan tinggi sampai PAUD (bangkok.unesco.org, 2020). Sangkhom Islam Wittaya School sebagai salah satu lembaga pendidikan yang mengelola PAUD menerapkan kebijakan study from home (belajar dari rumah) sejak bulan Februari sampai dengan waktu yang belum ditentukan karena menunggu informasi dan kebijakan dari pemerintah Kerajaan Thailand.

Study from home menjadi tantangan tersendiri bagi lembaga PAUD karena situasi ini datang secara tiba-tiba, tanpa ada perencanaan sebelumnya. Guru harus bekerja lebih keras untuk mendesain materi-materi pembelajaran berbasis teknologi yang belum pernah dilakukan sebelumnya. Orang tua di rumah juga belum sepenuhnya memiliki kesiapan, baik dari segi waktu, keterampilan, materi, maupun sarana dan prasarana seperti yang anak-anak dapatkan ketika berada di sekolah. Sebuah penelitian tentang dampak pembelajaran online di Sekolah Dasar menunjukkan beberapa kendala, baik dari perspektif siswa, guru, maupun orang tua. Dari perspektif siswa, study from home dianggap sebagai hari libur karena mereka tidak terbiasa dengan aktivitas belajar dari rumah. Anak juga cenderung merasa bosan dengan rutinitas yang terkesan hanya mengerjakan tugas yang selalu monoton dengan fasilitas yang kurang memadai. Sedangkan bagi guru, belajar dan mengajar dari rumah secara online bukan perkara yang mudah karena banyak guru yang gagap teknologi dan belum bisa mengembangkan kegiatan pembelajaran yang menyenangkan melalui teknologi. Kemudian bagi orang tua, mendapatkan tugas tambahan sebagai guru di rumah menjadi kendala tersendiri karena haru berbagi waktu dengan tugas-tugas kantor maupun rumah tangga. Orang tua juga harus mengeluarkan biaya yang lebih besar untuk membeli paket data internet agar memperlancar kegiatan belajar bersama anak dan berkomunikasi atau membuat laporan kepada guru (Purwanto et al., 2020).

Kondisi seperti hasil penelitian di atas pasti dialami oleh seluruh lembaga pendidikan pada setiap jenjang, tidak terkecuali lembaga PAUD karena kondisi ini muncul secara tiba-tiba dan belum pernah dialami oleh lembaga PAUD sejak pertama berdiri. Oleh sebab itu, guru harus berusaha mengembangkan berbagai strategi dalam mengatasi permasalahan-permasalah tersebut, sehingga tujuan pembelajaran yang sudah direncanakan di awal tahun pelajaran bisa tercapai meskipun harus menghadapi berbagai kendala.

Penelitian ini bertujuan untuk mengidentifikasi dan mendeskripsikan berbagai problematikan yang terjadi pada pembelajaran Bahasa Inggris untuk anak usia dini di Sangkhom Islam Wittaya School Thailand serta strategi guru dalam mencapai tujuan pembelajaran Bahasa Inggris selama study from home di masa pandemi COVID-19. Strategi yang diterapkan oleh guru merupakan usaha untuk menghadirkan solusi bagi anak dalam mencapai tujuan pembelajaran meskipun tidak melaksanakan aktivitas di sekolah. Belajar yang selama ini dilaksanakan di sekolah dipindahkan ke rumah masing-masing dengan bantuan orang tua sebagai fasilitator dan pendamping. 
Dalam setiap kegiatan pembelajaran di PAUD, probematika yang terjadi sangat beragam, terlebih pada situasi yang bersifat insidental dan serba tidak menentu seperti saat ini. Hasil penelitian menunjukkan beberapa problematika yang muncul dalam pembelajaran di masa pandemi dibagi menjadi tiga kategori, yaitu: pedagogi, teknologi, dan ekonomi (Muhdi \& Nurkholis, 2020). Dalam hal pedagogi, guru PAUD di Thailand juga masih perlu ditingkatkan secara berkelanjutan karena sebagian guru PAUD bukan merupkan sarjana di bidang PAUD (Chuenpraphanusorn et al., 2016)

Problematika yang berhubungan dengan pedagogi meliputi: tidak adanya pelatihan, kurangnya pengalaman, penguasaan TIK rendah, keterbatasan waktu, serta kurangnya kepedulian orang tua dalam mendampingi anak belajar. Sedangkan problematikan yang berhubungan dengan teknologi meliputi: kurangnya prasarana berupa jaringan internet/wifi, lemahnya signal, belum memiliki smartphone android. Selanjutnya problematikan yang berhubungan dengan ekonomi antara lai: kehilangan pekerjaan, penghasilan berkurang, tingkat kemiskinan meningkat, harga kuota atau paket data yang cukup tinggi.

Pada era revolusi industry 4.0 ini sebenarnya guru dituntut untuk selalu melakukan inovasi dalam pembelajaran, bukan hanya karena adanya pandemi. Berbagai strategi harus selalu dikembangkan sesuai dengan kebutuhan zaman, misalnya berupaya meningkatkan kemampuan literasi digital atau memahami berbagai media pembelajaran berbasis online maupun teknologi informasi. Meskipun kehadiran guru tidak akan bisa tergantikan oleh media secanggih apapun, tetapi media dapat mempermudah pekerjaan guru dalam memberikan pemahaman kepada siswa (Maulana \& Nurhafizah, 2019). Hal tersebut merupakan bagian dari ciri-ciri guru profesional yang tugasnya seperti tertuang dalam undang-undang guru dan dosen nomor 14 tahun 2005 BAB IV pasal 20 yaitu merencanakan pemebelajaran, melaksanakan proses pembelajaran yang bermutu, serta menilai dan mengevaluasi hasis pembelajaran (Safitri, 2019). Salah satu tugas guru dalam undangundang tersebut mewajibkan guru untuk merencankan dan melaksanakan proses pembelajaran yang bermutu, sedangkan proses pembelajaran bermutu membutuhkan strategi pembelajaran yang tepat dan inovatif.

Strategi dalam kamus besar bahasa Indonesia berarti rencana yang cermat mengenai kegiatan untuk mencapai sasaran khusus (Kemendikbud, 2020). Sedangkan menurut Schmeck, strategi pada dasarnya adalah istilah dalam dunia militer yang merujuk pada prosedur untuk mengimplementasikan rencana operasi militer berskala besar. Kemudian secara umum diartikan sebagai sebuah implementasi seperangkat prosedur atau taktik untuk menyelesaikan seseuatu (Schmeck, 1988). Pembelajaran merupakan proses kegiatan pengelolaan suatu lingkungan tertentu dengan tujuan agar orang dapat terlibat untuk mencapai perubahan tingkah laku dan merespon terhadap situasi tertentu (Hanafi, Adu, \& Muzakkir, 2018).

Strategi pembelajaran merupakan pemikiran atau tingkah laku tertentu yang digunakan seseorang untuk membantunya dalam memahami, mempelajari, atau menguasasi informasi atau pengetahuan baru (O'Malley \& Chamot, 1995). Dalam konteks pembelajaran Bahasa Inggris, strategi merupakan pemikiran atau langkah-langkah yang digunakan untuk membantu dalam menguasasi materi Bahasa Inggris.

Menurut Oxford (1990), strategi pembelajaran bahasa Inggris dikategorikan menjadi dua, yaitu strategi langsung dan tidak langsung. Strategi pembelajaran langsung meliputi memory strategy, cognitive strategy, dan compensation strategy. Sedangkan strategi pembelajaran tidak langsung meliputi metacognitive strategy, affective strategy, dan social strategies. Dua strategi ini saling melengkapi dan pelajar perlu menerapkan keduanya dalam pembelajaran bahasa yang efektif (Platsidou \& Athena, 2014). 


\section{METODOLOGI}

Penelitian ini menggunakan metode kualitatif deskriptif dengan pendekatan studi kasus, yaitu proses untuk memahami, menelaah, menjelaskan, dan menguji secara konprehensif, intensif, dan detail tentang sesuatu (Suwendra, 2018). Lokasi penelitian adalah di Anuban (PAUD) Sangkhom Islam Wittaya School Thailand. Subyek penelitian adalah 3 orang guru mata pelajaran Bahasa Inggris yang mengajar di kelompok usia 5-6 tahun.

Dalam mengumpulkan data, peneliti menggunakan wawancara semi-terstruktur kepada guru pengampu mata pelajaran Bahasa Inggris, kepala sekolah, pengelola yayasan, dan salah satu orang tua siswa. Wawancara dilakukan antara kurun waktu bulan Mei-Juni 2020 melalui media sosial facebook dan whatasapp dengan menggunakan bahasa Indonesia dan Inggris. Tiga orang guru yang mengajar bahasa Inggris di sana merupakan orang Indonesia, sedangkan kepala sekolah, pengelola yayasan, dan orang tua siswa merupakan orang asli Thailand yang bisa berbahasa Inggris dan Melayu.

Selain itu, data juga didapatkan dari berbagai dokumen kegiatan pembelajaran yang dapat diakses melalui media sosial. Sedangkan teknik analisis data mengacu pada konsep Miles \& Hubermanmelalui tahapan pengumpulan data, reduksi data, penyajian data, dan penarikan kesimpulan atau verifikasi. Pada tahap akhir, peneliti melakukan uji keabsahan data yang didapatkan melalui proses triangulasi dengan menggali informasi kepada orang tua siswa dan 2 orang guru Thailand yang salah satunya alumni dari kampus Indonesia. Desain penelitian ditunjukkan pada bagan di bawah ini (Hewi \& Asnawati, 2021):

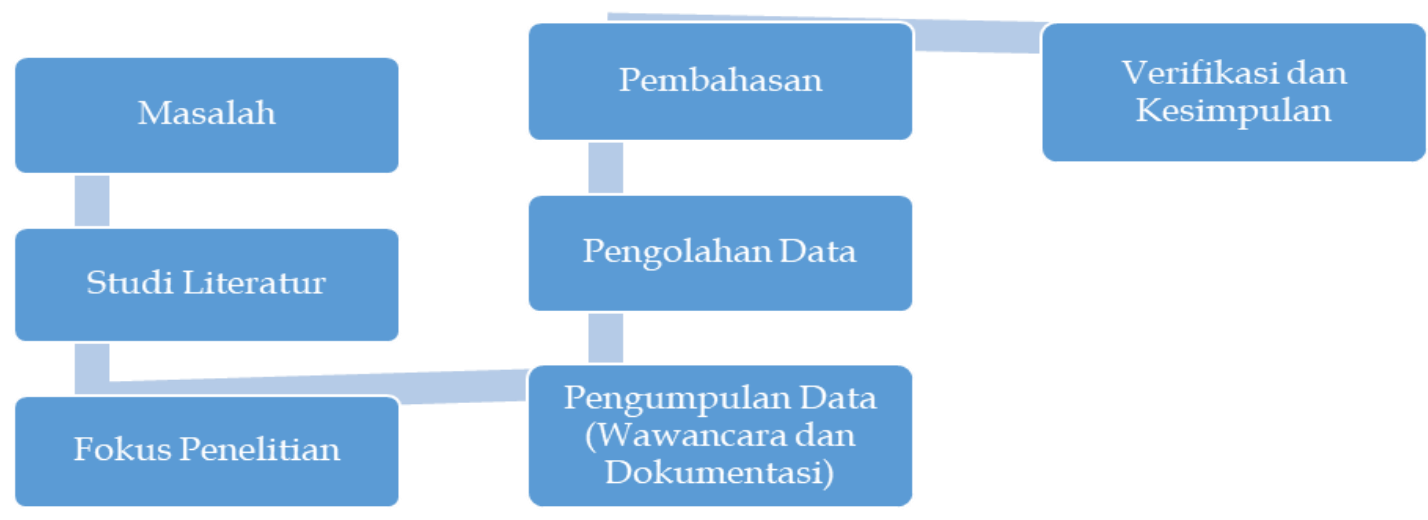

Bagan 1 Desain penelitian

\section{HASIL DAN PEMBAHASAN}

\section{Problematika Pembelajaran Bahasa Inggris Anak Usia Dini}

Musibah pandemi COVID-19 yang muncul secara tiba-tiba menimbulkan kepanikan di berbagai belahan dunia, termasuk di Thailand. Thailand adalah negara pertama yang mengkonfirmasi kasus positif COVID-19 di kawasan ASEAN pada tanggal 13 Januari 2020 (Wikipedia, 2020). Secara perlahan kasus positif semakin meningkat sampai akhirnya pemerintah Kerajaan Thailand memutuskan untuk memberlakukan pembatasan sosial (lockdown), termasuk memindahkan kegiatan pembelajaran di semua jenjang pendidikan ke rumah masing-masing (webfact, 2020).

Aktivitas work/study from home ini menjadi tantangan tersendiri bagi guru dan orang tua karena hal ini belum pernah mereka alami sebelumnya. Kolaborasi antara guru dan orang tua menjadi kunci utama dalam kesuksesannya. Menurut penelitian yang pernah peneliti lakukan (Qadafi, 2019), kolaborasi yang baik antara guru dan orang tua memberikan dampak yang positif terhadap perkembangan moral agama anak usia dini. Peneliti meyakini kolaborasi yang baik ini pasti akan memberikan dampak yang baik pada semua aspek, termasuk dalam pembelajaran Bahasa Inggris. 
Namun demikian, mengharapkan kolaborasi yang baik belum tentu bisa dilakukan mengingat kondisi yang tejadi sekarang sangat berbeda karena $100 \%$ kegiatan belajar dilaksanakan di rumah dan guru hanya menfasilitasi dari jarak jauh. Dalam beradaptasi dengan kondisi yang baru, guru setidaknya harus belajar hal-hal baru, terutama yang berkaitan dengan penggunaan teknologi. Orang tua juga dituntut untuk memiliki waktu yang lebih banyak bersama anak, memahami teknologi, dan menyiapkan biaya yang lebih besar untuk tetap urusan internet. Hasil penelitian terhadap tiga orang ayah dan enam orang ibu di Indonesia menunjukkan adanya peran yang signifikan dalam mengerjakan tugas sekolah dan melakukan komunikasi yang intens dengan anak selama kebijkan work/study from home (Kurniati, Kusumanita, Alfaeni, \& Andriani, 2021). Kasus masing-masing orang tua tentu saja akan berbeda-beda, tergantung dari kondisi setiap keluarga.

Hasil wawancara dengan salah seorang guru Bahasa Inggris, berasal dari Kota Palembang, Indonesia, menunjukkan adanya beberapa problematika yang muncul ketika peraturan belajar dari rumah ditetapkan. Problematika tersebut bisa berasal dari guru, siswa, orang tua siswa, dan hal-hal penunjang lainnya, seperti ketersediaan sarana dan prasarana yang mendukung kegiatan pembelajaran jarak jauh (tanpa tatap muka secara langsung).

Pertama, permasalahan guru terkait dengan perubahan berbagai metode dan aktivitas belajar yang sudah dirancang pada awal semester. Salah satu contoh dalam kegiatan normal, guru dapat menggunakan metode bernyanyi untuk mengajarkan materi alphabet (A-Z) sambil memperagarakan gerakan-gerakan bersama siswa dan membimbing siswa yang terlihat belum mampu bernyanyi. Namun ketika guru harus membuat video lagu alphabet, guru tidak akan bisa merasakan kedekatan bersama siswa sambil membimbing siswa yang belum mampu. Sedangkan orang tua di rumah memiliki style yang berbeda-beda dalam mengajarkan anak-anaknya.

Kedua, permasalah siswa berupa adanya stigma bahwa kegiatan belajar (sekolah) harus di lembaga pendidikan, saat berada di rumah itu berarti sedang libur. Merubah kebiasaan dan cara pandang anak tentang sekolah menjadi problematika yang cukup menguras tenaga orang tua, apalagi jika anak belum terbiasa dengan pola pendidikan yang teratur saat berada di rumah. Selain itu, anak sering merasa enggan belajar bersama orang tua karena orang tua belum tentu memiliki kompetensi yang sama dengan guru di sekolah.

Ketiga, orang tua sebagai aktor sentral dalam pendidikan di rumah juga tidak luput dari berbagai permasalahan. Saat siswa belajar dari rumah, orang tua memiliki tambahan pekerjaan selain pekerjaan pokok sebagai guru/pegawai, pedagang, dan petani (mayoritas bertani karet). Orang tua belum semuanya bisa membagi waktu untuk mendampingi anak belajar dan menyelesaikan tugas-tugas lainnya.

Selain itu, masalah keterampilan menggunakan perangkat bekerja berbasis IT dan internet juga merupakan tantangan tersendiri dan membutuhkan waktu untuk beradaptasi. Meskipun demikian, sebagian besar orang tua siswa cukup familiar dengan perangkat elektrotik (tablet, laptop/computer, dan smart phone) dan aktif menggunakan berbagai media sosial seperti facebook, youtube, dan line. Sehingga, sebagian kecil saja yang akan mengalami kendala dan butuh bantuan dalam menjalankan peran sebagai fasilitator anak ketika belajar di rumah.

Dalam konteks pembelajaran Bahasa Inggris, banyak orang tua yang memiliki kemampuan Bahasa Inggris di bawah rata-rata dari semua keterampilan, baik keterapilan membaca (reading), menulis (writing), berbicara (speaking) dan mendengar (listening), bahkan membaca abjad latin saja belum tentu bisa. Hal ini didukung oleh hasil survey kemampuan Bahasa Inggris masyarakat Thailand termasuk dalam kategori sangat rendah dan berada pada urutan ke 74 dari 100 negara yang disurvey di seluruh dunia jauh di bawah Indonesia pada urutan ke 61 (EPI, 2019).

Problematika terakhir adalah berkaitan dengan aspek pendukung pembelajaran berupa sarana/prasarana atau infrastruktur dasar berupa kemudahan akses internet dan bantuan dari pemerintah/yayasan untuk meringankan beban orang tua maupun guru yang 
harus mengeluarkan biaya tambahan untuk menyediakan berbagai perangkat belajar maupun untuk mengakses internet.

\section{Solusi Terhadap Problematikan yang Terjadi}

Pendidikan dan kurikulum yang baik adalah yang bersifat fleksibel, artinya dapat memberikan kesempatan kepada guru untuk mengembangkan program pembelajaran yang sesuai dengan kondisi yang ada, termasuk pada kondisi pandemi COVID-19 (Munandar, 2018). Kehidupan yang serba dinamis tidak boleh menjadi alasan untuk tidak melaksanakan proses pendidikan karena sejatinya setiap tempat adalah sekolah dan setiap orang atau makhluk ciptaan Allah adalah guru.

Sejak pertama diumumkan untuk belajar/bekerja dari rumah, pihak sekolah langsung menyampaikan informasi tersebut kepada orang tua melalui group media sosial (line) yang sudah lama dibentuk sebagai wadah berkomunikasi antara guru dan orang tua siswa. Pengelola yayasan dan para guru mulai mempersiapkan berbagai materi untuk disampaikan secara online melalui media sosial (facebook, line, youtube) dan pada semester berikutnya akan mulai menggunakan google classroom.

Dalam pembelajaran Bahasa Inggris, guru menyiapkan materi dalam bentuk video dan lembar-lembar kerja yang dibagikan melalui media sosial (line). Contoh video dapat diakses pada akun "Diah Rafika" (Rafika, n.d.). Untuk mengantisipasi orang tua yang tidak memiliki skill Bahasa Inggris, guru Bahasa Inggris yang berasal dari Indonesia bekerja sama dengan guru Bahasa Inggris lokal untuk menerjemahkan hal-hal yang perlu disampaikan ke orang tua terkait dengan kegiatan belajar dan tugas yang diberikan.

Menurut teacher Diah dalam wawancara dengan peneliti, video dan lembar-lembar tugas dibuat semudah mungkin agar siswa dapat mengerjakannya tanpa harus bergantung dengan orang tua, sehingga siswa tetap dapat belajar dan mengerjakan tugas tanpa harus selalu didampingi oleh orang tua. Ini menjadi salah satu solusi agar orang tua tetap dapat bekerja dan mendapatkan pemasukan untuk keberlangsungan hidup dan memfasilitasi berbagai kebutuhan belajar siswa di rumah.

Pernyataan yang sama juga disampaikan oleh teacher Wawan bahwa setiap membuat video pembelajaran, guru terlebih dahulu menyampaikan tujuan utama dari video tersebut dengan menggunakan bahasa Inggris dan terjemahan bahasa Thai. Video dibuat dalam durasi yang singkat dan materi yang langsung to the point agar mudah dimengerti tanpa harus memahami instruksi secara utuh. Menurut Mr. Jakaria dalam wawancara dengan peneliti, video dan tugas yang diberikan sangat mudah dimengerti. Kadang-kadang anaknya mengerjakan tugas tanpa harus dibimbing oleh orang tua karena sanga mudah dan disertai contoh.

Contoh video pembelajaran yang diberikan berupa satu atau dua kosa kata yang diucapkan berulang-ulang secara perlahan, ditambah dengan lagu-lagu atau gerakangerakan yang dapat ditirukan oleh orang tua dan siswa di rumah. Setelah menonton video, siswa diberikan tugas yang berkaitan dengan isi video. Tugas yang diberikan misalnya mengulangi kata-kata yang diucapkan oleh guru di dalam video atau menyesuaikan kata dengan gambar yang sudah disiapkan dalam worksheet.

Penggunaan lagu dalam pembelajaran bahasa Inggris memiliki beberapa manfaat, yaitu: sumber pengenalan bahasa baru yang didalamnya terdapat banyak kosa kata, menyenangkan dan dapat memupuk persepsi yang baik terhadap bahasa Inggris, meningkatkan daya ingat, konsentrasi, dan koordinasi. Dalam pelajaran pronunciation, lagu merupakan metode yang paling tepat dan sangat menyenangkan (Sophya, 2013).

Apabila terdapat kendala yang dihadapi orang tua dalam mengirimkan tugas yang telah diselesaikan karena faktor kesibukan, jaringan internet, atau hal-hal lain, guru tidak terlalu memaksa dan membebaninya dengan memberikan deadline tertentu. Orang tua bisa mengumpulkan tugas anak saat mereka memiliki waktu luang atau saat ada orang yang bisa membantu. Guru menyiapkan list nama-nama siswa yang sudah mengumpulkan tugas, 
sehingga orang tua dapat mengetahui apakah mereka sudah mengumpulkan tugas atau belum.

Menurut infromasi dari teacher Wawan, untuk memberikan kemudahan dalam pembelajaran online, pemerintah kerajaan Thailand berperan aktif untuk membantu warganya, terutama dalam mengakses internet. Pemerintah memberikan kuota internet gratis untuk mengakses berbagai platform pembelajaran online. Selain itu, pemerintah juga bekerja sama dengan stasiun televis untuk menayangkan siaran-siaran pendidikan pada setiap jenjang, termasuk PAUD.

\section{Strategi Guru dalam Pembelajaran Bahasa Inggris saat Study from Home}

Kemunculan virus COVID-19 secara tiba-tiba menyebabkan kepanikan di berbagai lembaga pendidikan, tidak terkecuali di Sangkhom Islam Wittaya School. Kebijakan work/study from home merupakan hal baru sepanjang sejarah berdirinya sekolah, sehingga hal ini menuntut para pimpinan dan guru untuk meredesain rencana kegiatan pembelajaran yang semula dengan konsep sekolah menjadi rumah dengan segala sarana, prasarana, dan sumberdaya yang ada. Menurut wawancara

Strategi pertama yang dilakukan oleh guru saat terjadi pandemi dan kebijakan work/study from home adalah memastikan orang tua mengetahui informasi ini karena orang tua adalah mitra guru dalam pendidikan anak saat berada di rumah masing-masing. Di Sangkhom Islam Wittaya School, semua guru kelas memiliki group bersama orang tua di media sosial, khususnya aplikasi line. Hal ini sudah berlangsung lama karena guru menyadari bahwa mitra terbaik dalam pendidikan anak adalah orang tua. Berbagai hal yang terjadi di sekolah, baik yang berhubungan dengan masalah akademik maupun non akademik akan disampaikan oleh guru melalui media sosial tersebut. Begitu juga sebaliknya, orang tua dapat menggunakan group media sosial untuk melaporkan berbagai hal tentang anak saat berada di rumah.

Strategi kedua adalah menyiapkan video pembelajaran yang sederhana dan tidak terlalu panjang. Video pembelajaran dibuat dengan cara yang menyenangkan, mudah ditiru, interaktif, dan disertai subtitle, gerakan, serta gambar untuk memudahkan siswa dan orang tua dalam membaca/memahami apa yang disampaikan oleh guru. Sebelum membuat video, guru membuat rencana dan script yang harus didiskusikan dengan guru-guru lain dan supervisor, pakar dari New Zealand. Setelah mendapatkan masukan, proses rekaman dimulai dan siap untuk dibagikan kepada orang tua siswa melalui group media sosial.

Strategi ketiga yaitu menyiapkan platform pembelajaran online yang dijadikan tempat menyimpan dan berbagi berbagai kegiatan pembelajaran yang telah disiapkan, seperti mengupload video pembelajaran melalui platform youtube, kemudian membagi link video di line group sesuai dengan tema pembelajaran pada hari itu. Selain itu, guru juga menggunakan media sosial line untuk membagi file yang berisi gambar terkait materi, misalnya untuk materi anggota tubuh, maka guru akan menyiapkan gambar anggota tubuh lengkap dengan tulisan Bahasa Inggrisnya.

Saat ini, guru juga sedang menyiapkan google classroom sebagai pengganti media sosial line group. Media sosial line group akan digunakan untuk sharing dan konsultasi, sedangkan kegiatan pembelajaran akan terfokus di platform google classroom. Orang tua akan diinformasikan kembali dan diberikan penjelasan terkait penggunaan google classroom untuk mengurangi resiko kesalahpahaman antara guru dan orang tua serta orang tua dan anak.

\section{SIMPULAN}

Kehidupan yang selalu dinamis dan penuh dengan ketidakpastian menimbulkan berbagai promlematikan bagi guru, khususnya guru Bahasa Inggris untuk anak usia dini. Problematika yang muncul bisa berasal dari guru, siswa, orang tua, maupun unsur penunjang lainnya. Terdapat beberapa strategi yang dilakukan oleh guru Bahasa Inggris dalam menyikapi kebijakan study from home, yaitu: menjalin komunikasi dengan orang tua 
siswa untuk memberikan penjelasan terkait dengan rencana kegiatan belajar saat siswa berada di rumah, membuat materi pembelajaran menggunakan video maupun lembarlembar kegiatan atau tugas, dan menyiapkan platform pembelajaran online untuk memudahkan orang tua mengakses berbagai materi dan memberi feedback terhadap tugas yang diberikan oleh guru.

\section{UCAPAN TERIMA KASIH}

Peneliti mengucapkan terima kasih kepada guru Bahasa Inggris di Anuban (PAUD) Sangkhom Islam Wittaya School Thailand yang telah memberikan informasi terkait dengan penelitian ini. Ucapan terima kasih juga kepada istri yang selalu memeberikan support dalam menyelesaikan paper ini.

\section{DAFTAR PUSTAKA}

Arango, C. (2020). Lessons Learned From the Coronavirus Health Crisis in Madrid, Spain: How COVID-19 Has Changed Our Lives in the Last 2 Weeks. Biological Psychiatry, 12. https:// doi.org/10.1016/j.biopsych.2020.04.003

bangkok.unesco.org. (2020). Education Minister Nataphol Teepsuwan on COVID-19 strategy in Thailand. Retrieved from https://bangkok.unesco.org/content/educationminister-nataphol-teepsuwan-covid-19-strategy-thailand

Chuenpraphanusorn, T., Boonchart, J., Chombuathong, S., Thitipetchkool, C., Moonlaphat, K., \& Snguanyat, O.-O. (2016). The Standard' s Development of Kindergarten Teachers of the Department of Local Administration, Thailand by "Coaching and Mentoring " method under the model of " On the Job Training " Asst . Prof . Dr . Teeradet Chuenpraphanusorn Ms . Kanchulee Moonlap. Mediterranean Journal of Social Sciences, 7(4), 353-362. https://doi.org/10.5901/mjss.2016.v7n4p

EPI, E. (2019). The world's largest ranking of countries and regions by English skills. Retrieved July 4, 2020, from https:/ / www.ef.co.id/epi/

Greenstone, M., \& Nigam, V. (2020). Does Social Distancing Matter? Becker Friedman Institute for Economics Working Paper Series, (26). https://doi.org/https://dx.doi.org/10.2139/ssrn.3561244

Hanafi, H., Adu, L., \& Muzakkir. (2018). Profesionalisme Guru dalam Pengelolaan Kegiatan Pembelajaran di Sekolah (1st ed.). Yogyakarta: Deepublish.

Hewi, L., \& Asnawati, L. (2021). Strategi Pendidik Anak Usia Dini Era Covid-19 dalam Menumbuhkan Kemampuan Berfikir Logis Abstrak. Jurnal Obsesi : Jurnal Pendidikan Anak Usia Dini, 5(1), 158-167. https:/ / doi.org/10.31004/obsesi.v5i1.530

Kemendikbud. (2020). Kamus Besar Bahasa Indonesia Daring. Retrieved April 28, 2020, from https://kbbi.kemdikbud.go.id/entri/strategi

Kurniati, E., Kusumanita, D., Alfaeni, N., \& Andriani, F. (2021). Jurnal Obsesi : Jurnal Pendidikan Anak Usia Dini Analisis Peran Orang Tua dalam Mendampingi Anak di Masa Abstrak. Jurnal Obsesi: Jurnal Pendidikan Anak Usia Dini, 5(1), 241-256. https://doi.org/10.31004/obsesi.v5i1.541

Maulana, I., \& Nurhafizah. (2019). Analisis Kebijakan Pendidikan Anak Usia Dini di Era Revolusi Industri 4.0. Jurnal Pendidikan Tambusai, 3(1), 657-665. Retrieved from https://jptam.org/index.php/jptam/article/view/266

Muhdi, \& Nurkholis. (2020). Keefektivan Kebijakan E-Learning berbasis Sosial Media pada PAUD di Masa Pandemi Covid-19 Abstrak. Jurnal Obsesi: Jurnal Pendidikan Anak Usia Dini, 5(1), 212-228. https:/ / doi.org/10.31004/obsesi.v5i1.535

Munandar, A. (2018). Pengantar Kurikulum. (A. Munandar, Ed.) (1st ed.). Yogyakarta: Deepublish.

O’Malley, J. M., \& Chamot, A. U. (1995). Learning Strategies in Second Language Acquisition. New York: Cambridge University Press.

Platsidou, M., \& Athena, S. (2014). Exploring relationships with grade level, gender and 
language proficiency in the foreign language learning strategy use of children and early adolescents Exploring relationships with grade level, gender and language proficiency in the foreign language 1. International Journal of Research Studies in Language Learning, (June). https:/ / doi.org/10.5861/ijrsll.2014.778

Purwanto, A., Pramono, R., Asbari, M., Hyun, C. C., Wijayanti, L. M., Putri, R. S., \& Santoso, P. B. (2020). Studi Eksploratif Dampak Pandemi COVID-19 Terhadap Proses Pembelajaran Online di Sekolah Dasar. EduPsyCouns: Journal of Education, Psychology and Counseling, 2(1), 1-12. Retrieved from https://ummaspul.ejournal.id/Edupsycouns/article/view/397

Qadafi, M. (2019). Kolaborasi Guru dan Orang Tua dalam Mengembangkan Aspek Moral Agaram Anak Usia Dini. Awlady: Jurnal Pendidikan Anak, 5(1), 1-19.

Rafika, D. (n.d.). YouTube. Retrieved June 1, 2020, from https://www.youtube.com/channel/UCSC-Nlobdp9ur2fW102i6Lw

Safitri, D. (2019). Menjadi Guru Profesional. (S. Anwar, Ed.) (1st ed.). Tembilahan: PT. Indragiri Dot Com.

Schmeck, R. R. (Ed.). (1988). Learning Strategies and Learning Styles (1st ed.). New York: Plenum Press. https:/ / doi.org/10.1007/978-1-4899-2118-5

Sophya, I. V. (2013). Pembelajaran Bahasa Inggri Melalui Lagu pada Anak Usia Dini. Thufula: Jurnal Inovasi Pendidikan Guru Raudhatul Athfal, 1(1), 1-21.

Suwendra, I. W. (2018). Metodologi Penelitian Kualitatif dalam Ilmu Sosial, Pendidikan, Kebudayaan, dan Keagamaan. (I. B. A. L. Manuaba, Ed.). Badung: Nilacakra Publishing House.

webfact. (2020). PM Prayut puts decision on lockdown off by a week. Retrieved May 31, 2020, from https://forum.thaivisa.com/topic/1160690-pm-prayut-puts-decision-onlockdown-off-by-a-week/

WHO. (2020). Pertanyaan dan Jawaban Terkait Corona Virus. Retrieved June 9, 2020, from https://www.who.int/indonesia/news/novel-coronavirus/qa-for-public

Wikipedia. (2020). COVID-19 Pandemic in Thailand. Retrieved May 31, 2020, from https://en.wikipedia.org/wiki/COVID-19_pandemic_in_Thailand 